Article

\title{
Investigating the Long-Range Transport of Aerosol Plumes Following the Amazon Fires (August 2019): A Multi-Instrumental Approach from Ground-Based and Satellite Observations
}

Hassan Bencherif ${ }^{1,2, *} \mathbb{D}$, Nelson Bègue ${ }^{1}$, Damaris Kirsch Pinheiro ${ }^{3} \mathbb{D}$, David Jean du Preez ${ }^{1,4} \mathbb{D}$, Jean-Maurice Cadet ${ }^{1}{ }^{\circledR}$, Fábio Juliano da Silva Lopes ${ }^{5,6}$, Lerato Shikwambana ${ }^{7}$, Eduardo Landulfo ${ }^{6}\left(\mathbb{D}\right.$, Thomas Vescovini ${ }^{1}$, Casper Labuschagne ${ }^{8}\left(\mathbb{D}\right.$, Jonatan João Silva ${ }^{6,9}{ }^{(D)}$, Vagner Anabor ${ }^{3}$, Pierre-François Coheur ${ }^{10}$, Nkanyiso Mbatha ${ }^{11}{ }^{\mathbb{D}}$, Juliette Hadji-Lazaro ${ }^{12}$, Venkataraman Sivakumar ${ }^{2}$ id and Cathy Clerbaux ${ }^{10,12}$ (D)

1 Laboratoire de l'Atmosphère et des Cyclones (LACy, UMR 8105 CNRS, Université de la Réunion, Météo-France), Université de La Réunion, 97400 La Réunion, France; Nelson.begue@univ-reunion.fr (N.B.); dupreez.dj@tuks.co.za (D.J.d.P.); jean.cadet@univ-reunion.fr (J.-M.C.); thomas.vescovini@gmail.com (T.V.) School of Chemistry and Physics, University of KwaZulu-Natal, Durban 4041, South Africa; venkataramans@ukzn.ac.za

3 Federal University of Santa Maria, Santa Maria, RS 97105-900, Brazil; damaris@ufsm.br (D.K.P.); vanabor@gmail.com (V.A.)

4 Department of Geography, Geoinformatics and Meteorology, University of Pretoria, Pretoria 0002, South Africa

5 Environmental Science Department, Institute of Environmental, Chemical and Pharmaceutical Science, Federal University of São Paulo—UNIFESP, Rua São Nicolau, 210, Centro, Diadema, São Paulo 09913-030, Brazil; fabioslopes@gmail.com

6 Nuclear and Energy Research Institute (IPEN), Center for Lasers and Applications (CLA), São Paulo (SP) 05508-000, Brazil; elandulf@ipen.br (E.L.); silva.jonatan@ufob.edu.br (J.J.S.)

7 Earth Observation Directorate, South African National Space Agency, Pretoria 0001, South Africa; lshikwambana@gmail.com

8 South African Weather Service, Cape Point GAW, Stellenbosch 7600, South Africa; casper.labuschagne@weathersa.co.za

9 Center for Exact Sciences and Technologies (CCET), Federal University of Western Bahia (UFOB), Campus Barreiras, Barreiras, Bahia 47810-047, Brazil

10 Spectroscopy, Quantum Chemistry and Atmospheric Remote Sensing (SQUARES), Université libre de Bruxelles (ULB), Brussels 1050, Belgium; Pierre.Coheur@ulb.be (P.-F.C.); cathy.clerbaux@latmos.ipsl.fr (C.C.)

11 Department of Geography, University of Zululand, KwaDlangezwa 3886, South Africa; mbathanb@unizulu.ac.za

12 LATMOS/IPSL, Sorbonne Université, UVSQ, CNRS, 75005 Paris, France; juliette.hadji-lazaro@latmos.ipsl.fr

* Correspondence: hassan.bencherif@univ-reunion.fr; Tel.: +262-262-93-82-55

Received: 15 October 2020; Accepted: 19 November 2020; Published: 23 November 2020

check for updates Abstract: Despite a number of studies on biomass burning (BB) emissions in the atmosphere,
observation of the associated aerosols and pollutants requires continuous efforts. Brazil, and more
broadly Latin America, is one of the most important seasonal sources of BB, particularly in the
Amazon region. Uncertainty about aerosol loading in the source regions is a limiting factor in terms
of understanding the role of aerosols in climate modelling. In the present work, we investigated
the Amazon BB episode that occurred during August 2019 and made the international headlines,
especially when the smoke plumes plunged distant cities such as São Paulo into darkness. Here,
we used satellite and ground-based observations at different locations to investigate the long-range
transport of aerosol plumes generated by the Amazon fires during the study period. The monitoring
of BB activity was carried out using fire related pixel count from the moderate resolution imaging 
spectroradiometer (MODIS) onboard the Aqua and Terra platforms, while the distribution of carbon monoxide $(\mathrm{CO})$ concentrations and total columns were obtained from the infrared atmospheric sounding interferometer (IASI) onboard the METOP-A and METOP-B satellites. In addition, AERONET sun-photometers as well as the MODIS instrument made aerosol optical depth (AOD) measurements over the study region. Our datasets are consistent with each other and highlight AOD and $\mathrm{CO}$ variations and long-range transport of the fire plume from the source regions in the Amazon basin. We used the Lagrangian transport model FLEXPART (FLEXible PARTicle) to simulate backward dispersion, which showed good agreement with satellite and ground measurements observed over the study area. The increase in Rossby wave activity during the 2019 austral winter the Southern Hemisphere may have contributed to increasing the efficiency of large-scale transport of aerosol plumes generated by the Amazon fires during the study period.

Keywords: biomass burning; Amazonia; Brazil; aerosols; plume transport

\section{Introduction}

Carbonaceous aerosols constitute the major component of suspended particulate matter (PM). Exposure to aerosols may affect human health in the short and medium term. According to de Oliveira Alves et al. [1], more than 10 million people are directly exposed to high levels of pollutants resulting from deforestation and agricultural fires over the Brazilian Amazonian region. During the biomass burning season, high concentrations of $\mathrm{PM}_{10}$ have been measured (ranging from 400 up to $600 \mu \mathrm{g} \cdot \mathrm{m}^{-3}$ ) [2], exceeding the upper threshold of concentration established by the World Health Organization (daily exposure to $\mathrm{PM}_{10}: 50 \mu \mathrm{g} \cdot \mathrm{m}^{-3}$ ) by 8-12 times [1].

The primary source of carbonaceous aerosols in the Southern Hemisphere (SH) is from biomass burning (BB), and the most important source areas are Southern America and Southern Africa. These areas regularly experience biomass fires, usually during the dry season from July to October. Moreover, the effects of such fires were observed over millions of square kilometers, covering large areas, even far from the source region. Crutzen and Carmichael [3] stated that BB is the most important source of Carbon monoxide (CO) and aerosol loading in the tropics. The influence of BB on the tropical tropospheric composition and the associated transport schemes has been investigated via the analysis of ozone measurements [4-7]. Making use of Fourier transform infrared (FTIR) spectrometry and the FLEXPART model, Duflot et al. [8] showed that the Southern Africa and Southern America $\mathrm{BB}$ events have the potential to inject large amounts of ozone precursors such as $\mathrm{CO}$ and aerosols throughout the troposphere over the South-Western Indian Ocean basin. The bulk of BB activities in Southern America are widespread within the so-called "arc of deforestation" which refers to the region where the agricultural frontier extends into the forest and has the highest rates of deforestation in the South America. This region traverses the southern and eastern edges of the Amazon basin. This arc comprises both tropical rainforest and Cerrado (a tropical savannah ecoregion of Brazil) biomes, which feature distinct fire regimes. However, the distribution of BB may vary from year to year, depending on meteorology, dynamic context, and environmental conditions. Whether the vegetation is dead or alive can alter the emissions of gas species and aerosols. Torres et al. [9] reported August to be the peak of BB activity over Southern America, but the season extends up to November.

In spite of the fact that the transport of aerosols is fairly well documented in several publications [8,10-13], studies specifically investigating the long-range transport of the BB pollution from South America are sparse. Indeed, several questions on distribution of the aerosols and pollutants injected into the atmosphere, together with the associated long-range transport processes during the Southern America BB season require collaborative initiatives and multi-instrumental investigations.

Generally, during austral winter, the Amazonian forest is at a stage of intense fire activity. The present work was initiated following the August 2019 Amazon fire event that made the international 
media headlines, especially when the smoke plumes spread far from the Amazon region and reached the city of São Paulo (23,59 $\left.{ }^{\circ} \mathrm{S} 46,64^{\circ} \mathrm{W}\right)$, Brazil on 18 August (2019), more than $2700 \mathrm{~km}$ away and plunged it into darkness at 3pm. According to the Brazilian National Institute for Space Research (INPE; Instituto Nacional de Pesquisas Espaciais), Brazil's Amazon rainforest recorded a huge increase in fire related pixel count in $2019(+76 \%)$ in comparison with 2018 . However, Brazil was not the only country affected by the increase in Amazon fires. Other countries in the Amazon basin have also recorded a high number of fires during 2019 fire season. For Bolivia and Peru, the INPE estimated the change in fire related pixel count at $+79 \%$ and $+92 \%$, respectively.

In this paper, we utilize ground-based and satellite measurements to follow Amazon fire plumes during August 2019. The ground-based data comprises a set of five sun-photometers operating in Brazil, South Africa, and Reunion within the framework of AERONET (Aerosol Robotic NETwork) network, in addition to a LiDAR operating at São Paulo (Brazil) and a Picarro CRDS system operating in Cape Point (South Africa). Enhancements in CO concentrations and Aerosol Optical Depth (AOD) were observed and simulated by the Lagrangian transport model FLEXPART, providing evidence of long-range transport of fire emissions. The datasets and FLEXPART descriptions are given in Section 2, while Section 3 is dedicated to a description of the Amazon fires during August 2019 utilizing MODIS fire pixels together with $\mathrm{CO}$ and AOD distributions. Section 4 provides evidence on long-range and transatlantic transport. In the final section, we present a concluding discussion.

\section{Observations and Data Sets}

\subsection{Detection of Fire Pixels by MODIS}

Generally, forest fires have temperatures of the order of $800 \mathrm{~K}$ to $1000 \mathrm{~K}$, and therefore their radiance may show the maximum values at wavelengths between 3.5 and $4.0 \mu \mathrm{m}$ [14]. The most often used wavelengths for fire detection are around $3.9 \mu \mathrm{m}$. In the present study, we used data from the moderate resolution imaging spectroradiometry (MODIS) experiments onboard the Aqua and Terra platforms launched by NASA in 1999 and 2002, respectively. Aqua and Terra satellites have sun-synchronous orbits. Owing to its wide ground scan $(2330 \mathrm{~km})$ capability, the MODIS instrument takes one to two days to observe each point on the Earth surface, with a spatial resolution ranging from $0.25 \mathrm{~km}$ to $1.00 \mathrm{~km}$, depending on the channels used. MODIS performs measurements at 36 different bands ranging from 0.4 to $14.4 \mu \mathrm{m}$, and has infrared channels specifically designed for fire observations. This makes MODIS one of the primary reference instruments for fire detection and monitoring. Its principle of fire detection is based on a comparison of the brightness temperatures of two channels, i.e., $4 \mu \mathrm{m}$ and $11 \mu \mathrm{m}$, recorded for each $1-\mathrm{km}^{2}$ pixel [15]. If the brightness temperatures at $4-\mu \mathrm{m}$ and/or the difference between the brightness temperatures of the $4 \mu \mathrm{m}$ and $11 \mu \mathrm{m}$ channels are above a certain threshold, a fire is attributed to the pixel. When a detection is inconclusive, a "relative" detection is performed, based on the average values of the brightness temperatures observed in the surrounding pixels, unaffected by fires or cloud cover [16]. The MODIS fire products used in this study to investigate fire distributions across Brazil during the 2002-2019 period, originates from the following platform: https://earthdata.nasa.gov/earth-observation-data/near-real-time/firms/active-fire-data.

\subsection{CO Measurements from IASI}

Most of the $\mathrm{CO}$ emissions from BB occurs during the slow combustion phase, which is characterised by low heat production (temperature less than $850 \mathrm{~K}$ ) and a low decomposition rate. The main chemical reaction occurring at this temperature is that of oxygen with carbon, forming CO [16]. The infrared atmospheric sounding interferometer (IASI) onboard the MetOp satellite measures CO on a global scale, twice a day. IASI is an atmospheric sounder developed by CNES (Centre National des Etudes Spatiales) and the European Organization for the Exploitation of Meteorological Satellites (EUMETSAT). It was designed for global observations with a vertical range covering the troposphere and the lower stratosphere. This instrument is on board the MetOp-A, -B, and -C meteorological satellites, which have 
been operating since 2006, 2012, and 2018, respectively. The IASI atmospheric sounder uses a Fourier transform spectrometer, which measures the infrared radiation emitted by the Earth's surface and the different layers of the atmosphere at nadir, covering wavelengths from 6.62 to $15.5 \mu \mathrm{m}$, allowing for day and night measurements [17]. Retrieval of CO total columns and vertical profiles occur in near real-time from the nadir radiance spectra measured by the instrument in the thermal infrared (TIR) spectral range. George et al. [18] described the measurement of vertical sensitivity and provided a first assessment of the capabilities of IASI to measure CO distributions. Even though the CO profiles from IASI are indicative and the operational algorithm requires some improvements in the retrieval of plume injection-height, the CO product from IASI has been used previously in a number of studies in relation to fire emissions and transport [19-21]. Global distributions of CO columns were evaluated with correlative observations available from other nadir looking TIR missions. On average, they found total column discrepancies of about $7 \%$ in comparison with three other sounders.

In the present study, we used CO concentrations and columns from IASI instruments on MetOp-A and MetOp-B over the study area, i.e., Southern America, Atlantic, Southern Africa, and South-West of the Indian Ocean, from $0^{\circ}$ to $50^{\circ}$ South in latitude and from $100^{\circ}$ West to $60^{\circ}$ East in longitude (see Figure 1).

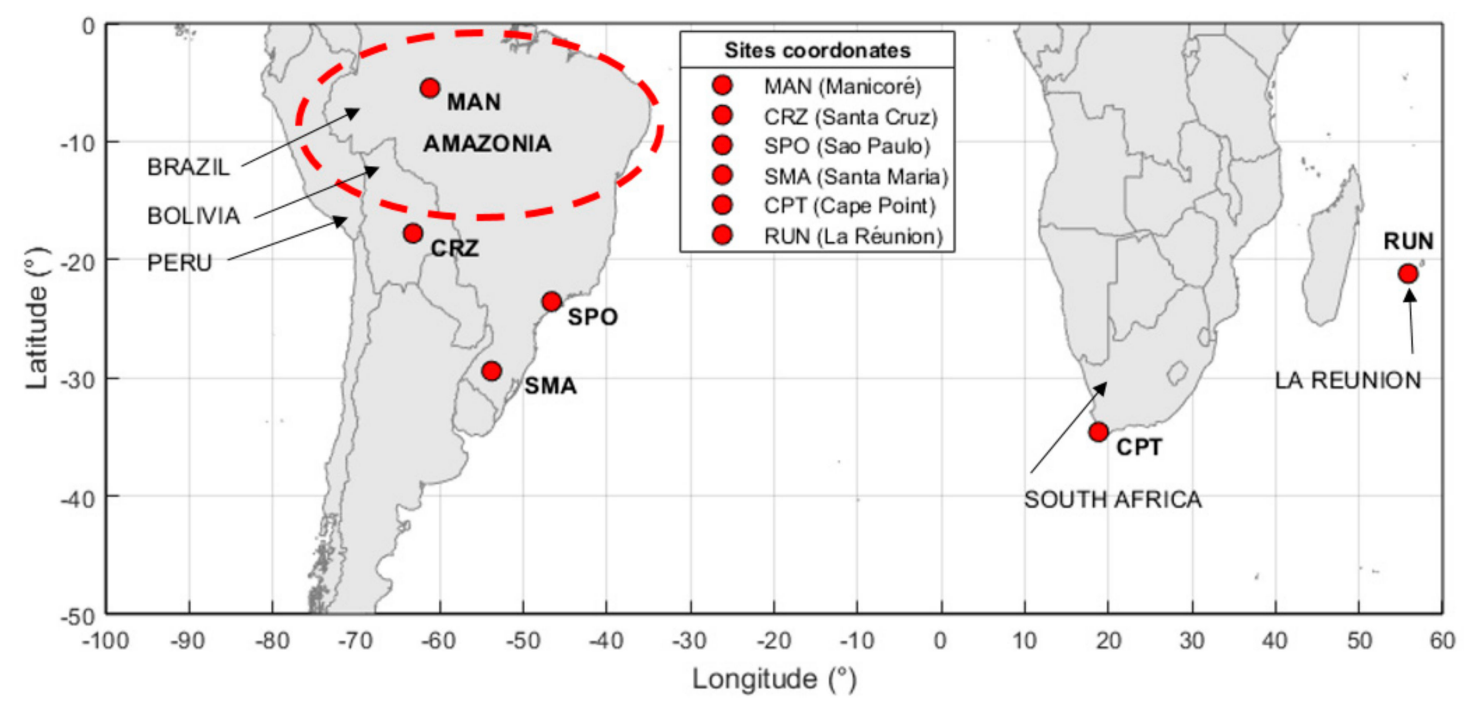

Figure 1. Map of the study area (Southern America, Atlantic Ocean, Southern Africa and South-West Indian Ocean), together with study sites depicted with red circles (see the legend).

\subsection{Aerosols Measurements from Ground}

\subsubsection{Sun-Photometer Data}

For the purpose of the present study, time-series of AOD recorded at the six selected sites as shown in Figure 1 (Santa Cruz $\left(17.78^{\circ} \mathrm{S}, 63.17^{\circ} \mathrm{W}\right)$, São Paulo $\left(23.59^{\circ} \mathrm{S}, 46.64^{\circ} \mathrm{W}\right)$, Santa Maria $\left(29.69^{\circ} \mathrm{S}, 53.80^{\circ} \mathrm{W}\right)$, Cape Point $\left(34.35^{\circ} \mathrm{S}, 18.49^{\circ} \mathrm{E}\right)$ and Reunion Island $\left(20.89^{\circ} \mathrm{S}, 55.48^{\circ} \mathrm{E}\right)$ ) were used. Except Manicoré $\left(5.80^{\circ} \mathrm{S}, 61.29^{\circ} \mathrm{W}\right)$ and Cape Point, all the study sites are equipped with a CIMEL sun-photometer instrument and operate in the framework of the AERONET network. A sun-photometer is an automatic diurnal and cloud-free passive remote sensing sensor. Holben et al. [22] give a detailed description of the CIMEL sun-photometer of the AERONET network and the associated data retrieval. Measurements are obtained at 15-min interval at eight wavelengths ranging from the UV to IR bands. The direct solar extinction and diffuse sky radiance measurements are used to compute AOD and to retrieve aerosol size distributions, using the methodology developed by Dubovik and King [23]. The estimated uncertainty in AOD measurements under cloud-free condition range from 0.01 to 0.02 [24-26]. Level 1.5 (Real Time Cloud screened) AOD values presented in this work, were selected and downloaded 
(http://aeronet.gsfc.nasa.gov) since level 2 data was not yet available at the time of this study. Based on finding by Gilles et al. [27], the level 1.5 (version 3) aerosol data are statistically very close to version 2 level 2.0. They also reported that stable thin cirrus becomes less of an issue (less residual contamination) with version 3 of AERONET level 1.5.

\subsubsection{IPEN LiDAR at Sao Paulo}

Among the study sites, only São Paulo (Brazil) is equipped with a multi-channel LiDAR (light detection and ranging) system. A LiDAR is an active remote sensing instrument usually based on the emission of a laser beam into the atmosphere [28]. Among other parameters, according to its technical configuration, a LiDAR system may allow measurements of aerosols profiles from the backscattered elastic and inelastic photons. The São Paulo LiDAR is a Rayleigh-Mie-Raman system operational at the Nuclear and Energy Research Institute (IPEN). Its emission source is a Nd:YAG laser emitting at 3 wavelengths, i.e., 1064, 532, and $355 \mathrm{~nm}$, with a repetition rate of $10 \mathrm{~Hz}$ and pulse durations of approximately 5 ns. Lopes et al. [29] provide extensive technical details on the IPEN LiDAR. This LiDAR system is part of the LALINET (Latin America Lidar Network, http://lalinet.org), a LiDAR network mainly dedicated to the measurement of aerosol and particle distributions over Latin America [30].

\subsubsection{The Picarro Instrument}

Cape Point $\left(\mathrm{CPT}, 34.35^{\circ} \mathrm{S}, 18.49^{\circ} \mathrm{E}\right)$ is a meteorological station operated by the South African Weather Service (SAWS) within the framework of the Global Atmosphere Watch (GAW) program of the World Meteorological Organization (WMO). It has the longest continuous atmospheric CO time-series in the SH, which started in 1977. The CPT trace gas observatory is located at the southern tip of the Cape Peninsula, about $60 \mathrm{~km}$ southeast of the Cape Town city. Despite its closeness to the city of Cape Town, the CPT site is considered as unaffected by urban pollution, due to the dominance of marine airflow patterns and air-mass identification protocols followed at the station [31]. Depending on altitude and season, the site is exposed to air masses from the South Atlantic and Southern Ocean [32,33]. A Picarro (model G2302) instrument provides the continuous CO measurements at CPT observatory since 2011. This gas analyzer, based on wavelength-scanned cavity ring down spectroscopy (WS-CRDS), is capable of measuring in the parts-per-billion ( $\mathrm{ppb}$ ) range, having a $\pm 2 \mathrm{ppb}$ sensitivity. The reproducibility and repeatability of the CRDS operated at the CPT station is determined using a daily flow of a target gas mixture containing a constant concentration. According to Labuschagne et al. [33], verification of the CPT Picarro instrument occurs bi-annually. In addition, the station participates in the WMO international Round Robin inter-comparison experiments, following the GAW calibration protocols. The analytical techniques used in measuring the historical $\mathrm{CO}$ data, show very good reproducibility and repeatability rates of $2.68 \%$ and $0.74 \%$ respectively. Furthermore, with regard accuracy, Chen et al. [34] used CO measurements in humid air by applying the CRDS technique. They reported small mean differences of $-0.6 \mathrm{ppb}$, between integrated in situ Picarro CRDS analyzer and flask measurements, displaying no significant linear trend. In the present study, we use the surface $\mathrm{CO}$ time-series recorded by Picarro at CPT in order to detect the CO anomalies observed during the study period, August 2019.

\subsection{FLEXPART Model}

The Lagrangian particle dispersion model FLEXPART (version 10.4) is very effective in simulating the transport, deposition (wet and dry), diffusion and first order chemical reactions of tracer particles released from point or area sources [35]. Version 10.4 of FLEXPART includes improvements in different aspects such as physicochemical parameterizations. Source identification occurs via the release of particles from a receptor location and the simulation of backward trajectories. According to Pisso et al. [35], the backward mode is more efficient when there are more sources than receptors.

In this study, wind field data from the European Centre for Medium-Range Forecasts (ECMWF) serves as input data. The ECMWF data has a 3-h temporal resolution, $1^{\circ}$ spatial resolution, and 138 
vertical levels. To determine the source of the $\mathrm{CO}$ increase, $\mathrm{CO}$ was used as tracer in the FLEXPART back trajectories. Many previous studies [36-38] utilised CO, which has a relatively long lifetime in the atmosphere [39]. In the simulations, a large number of CO particles ( 100000) were released between 0.5 and $6 \mathrm{~km}$ at 1-km intervals over Cape Point, South Africa. These particles cover a 6-h period from the times when the peaks in $\mathrm{CO}$ were observed at Cape Point and the simulations were run for 7 days. An output grid of $1^{\circ} \times 1^{\circ}$ was produced every $6 \mathrm{~h}$ at $500-\mathrm{m}$ intervals within the same altitude range in which the particles were released.

\section{Results}

In this section, we present $\mathrm{CO}, \mathrm{AOD}$, and fire distributions derived from IASI and MODIS observations over the study area (Southern America, Atlantic, Southern Africa and South-West of the Indian Ocean, see Figure 1) for the study period, August 2019. CO time-variations from IASI are examined by taking into account fire occurrence at the surface. In addition, we investigated ground-based AOD records from four sites (2 in Brazil, 1 in South Africa and 1 in Reunion Island) equipped with CIMEL sun-photometers.

\subsection{Fire Records from MODIS}

In the present work, MODIS fire products accounts for fire pixels over Brazil during the study period (August 2019), as well as for the previous years, from 2002 to 2019. The fire time-series used, was constructed from monthly counts to perform climatological and inter-annual analysis, as shown in Figure 2. Figure 2a depicts the monthly mean climatological numbers of fire pixels. As expected, the fire season in Brazil takes place from July to November, with peak activity during the period August-September [9]. On average, August is the second most active month for fires in Brazil $(\sim 85,000 \pm 45,000)$. One can note the high variability during the fire season, indicated by the superimposed standard deviation bars. This high variability could partly be associated to the significant reduction in fire records over the period of MODIS measurements (2002-2019). In fact, in agreement with the Global Forest Watch fire report (https://fires.globalforestwatch.org), the years with the highest fire count were primarily in the early 2000s, before 2010 (Figure not shown). Indeed, 2019 is not a record year in terms of fires in Brazil, but it is relatively high, when compared to recent years. It is the third-highest year over the last decade. As for Figure 2b, it compares fire pixels recorded for the months of July and August in Brazil over the five years: 2015, 2016, 2017, 2018, and 2019. It appears that August 2019 has the highest fire record over the last five years in Brazil and accounts for more than double the number of fires detected one year before.
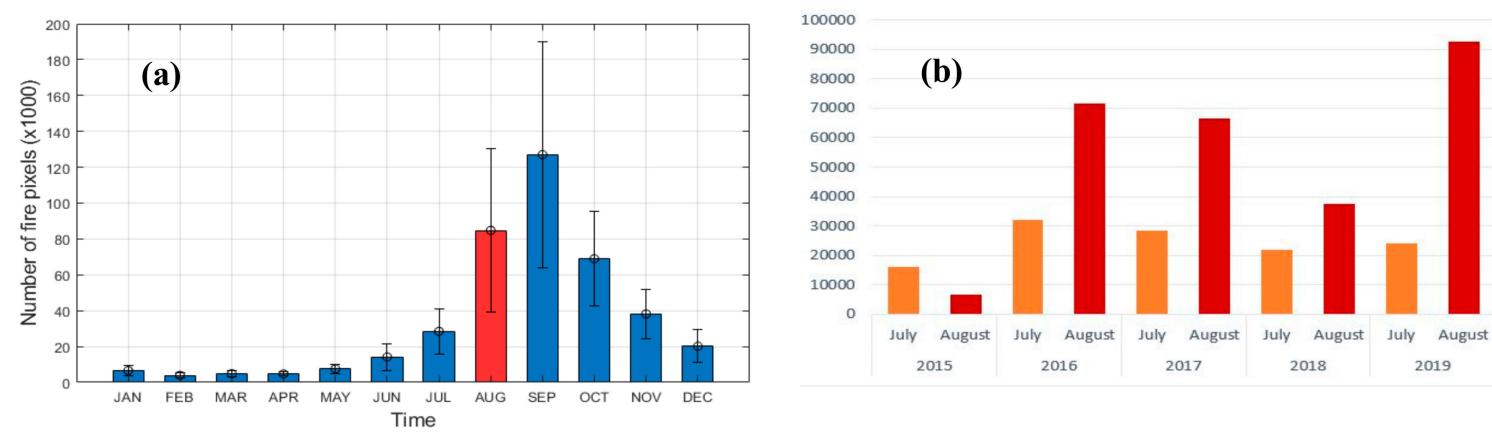

Figure 2. (a) Monthly fire pixels averaged over the 2002-2019 period from MODIS over Brazil. The vertical bars show the $\pm 1 \sigma$ variations. (b) July (in orange) and August (in red) cumulated fire pixels as detected by MODIS over Brazil from 2015 to 2019.

\subsection{Carbon Monoxide and AOD Variations}

Forest fires generate plumes of smoke and compounds resulting from incomplete combustion, which results in AOD and CO concentrations increase along transport pathways. As mentioned above 
in the previous section, distributions of total columns of CO and AOD at $550 \mathrm{~nm}$ wavelength are used over the study area during August 2019. Figure 3 shows AOD and CO distribution maps for the same selected dates (2, 9, 17 and 20 August 2019). MODIS AOD values are obtained by averaging observations from three days. It can be seen from the $\mathrm{CO}$ and $\mathrm{AOD}$ maps that the $\mathrm{SH}$ is characterized by two main fire zones, i.e., Africa and Latin America. Both fire zones are characterised by high AOD and $\mathrm{CO}$ values. At this stage in the present work, the focus was on the situation in Latin America resulting from the Amazon fires in order to analyse the transatlantic transport of plumes and pollutants. Overall, it should be noted that both AOD and CO distributions are consistent in space and time. During the first half of August, they showed a southward transport of fire plumes (plots (a) to (d)). It appears to be guided by the north-south oriented Andes Mountains, laying along the western coast of South America, crossing Brazil, Bolivia, Paraguay, Argentina, and Uruguay. Furthermore, according to AOD and CO maps on Figure 3, it can be inferred that the bulk of the 2019 Amazonia fires seemed to be from the southern and western the Amazon, and the first transatlantic transport event seems to take place far from the fire areas, at about $30^{\circ} \mathrm{S}$, with an eastward zonal flow. The transport direction changed a few days later. From 17 August, fire plumes moved south-eastward to reach the Brazilian Atlantic coast at about the $20^{\circ} \mathrm{S}$ latitude line, crossing the states of São Paulo and Rio de Janeiro on 19-20 August (see Figure 3g,h).

In Figure 4, the CO-IASI daily variations of the total column (upper graphs) and concentrations in different atmospheric layers are displayed for August 2019, over three Brazilian sites located between the equator and $30^{\circ} \mathrm{S}$ latitude: Manicoré $\left(5.8^{\circ} \mathrm{S}, 61.3^{\circ} \mathrm{W}\right)$, São Paulo $\left(23.5^{\circ} \mathrm{S}, 46.6^{\circ} \mathrm{W}\right)$ and Santa Maria $\left(29.4^{\circ} \mathrm{S}, 53.8^{\circ} \mathrm{W}\right)$. For comparison, the August $2018 \mathrm{CO}-\mathrm{IASI}$ values are superimposed in blue. At the three sites in 2019, IASI data is missing for the first 8-10 days of the month. Overall, regardless of the year, Manicoré consistently reports CO levels approximately twice that of any other site. This was consistent with the fact that Manicoré is located in the state of Amazonas, within the fire zone. The daily CO values obtained in 2019 were 1.5-2 times higher than in 2018, especially around 15 August and between 20 and 25 August. On the other hand, as shown by the curves of CO concentrations per layer (Figure 4a), the highest CO concentrations were located in the lower troposphere, from ground up to $3 \mathrm{~km}$. For the other two sites, it is shown that, apart from well-marked events, CO columns in 2019 are almost similar to those in 2018. For São Paulo, two peaks are noticeable: the peak around 18-19 August and another less pronounced peak around 27 August. For Santa Maria, there are also two peaks with a CO increase, on 18 and 26 August (see Figure 4). 

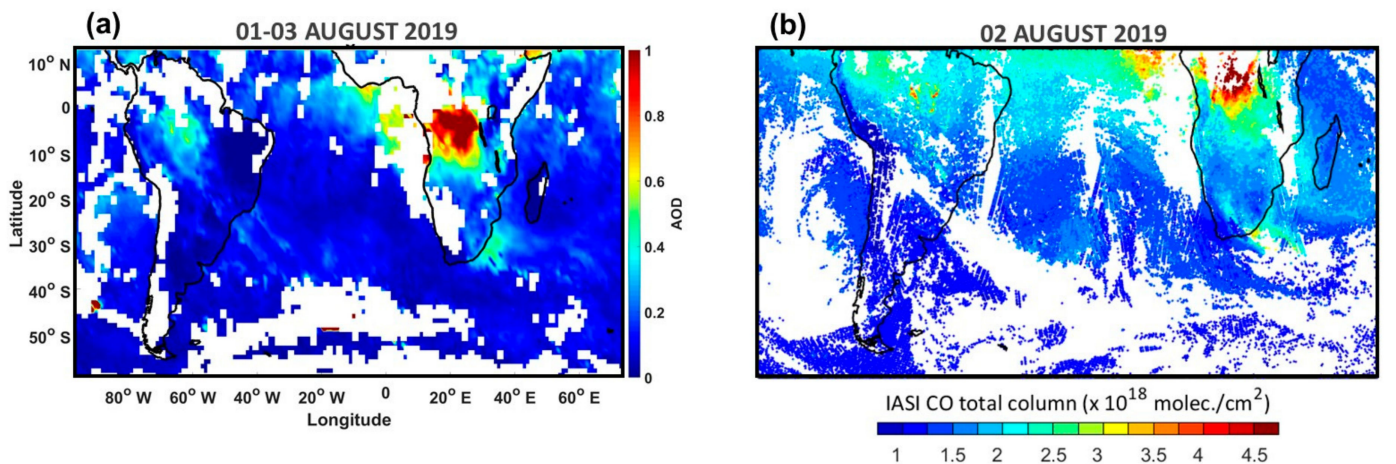

(c)
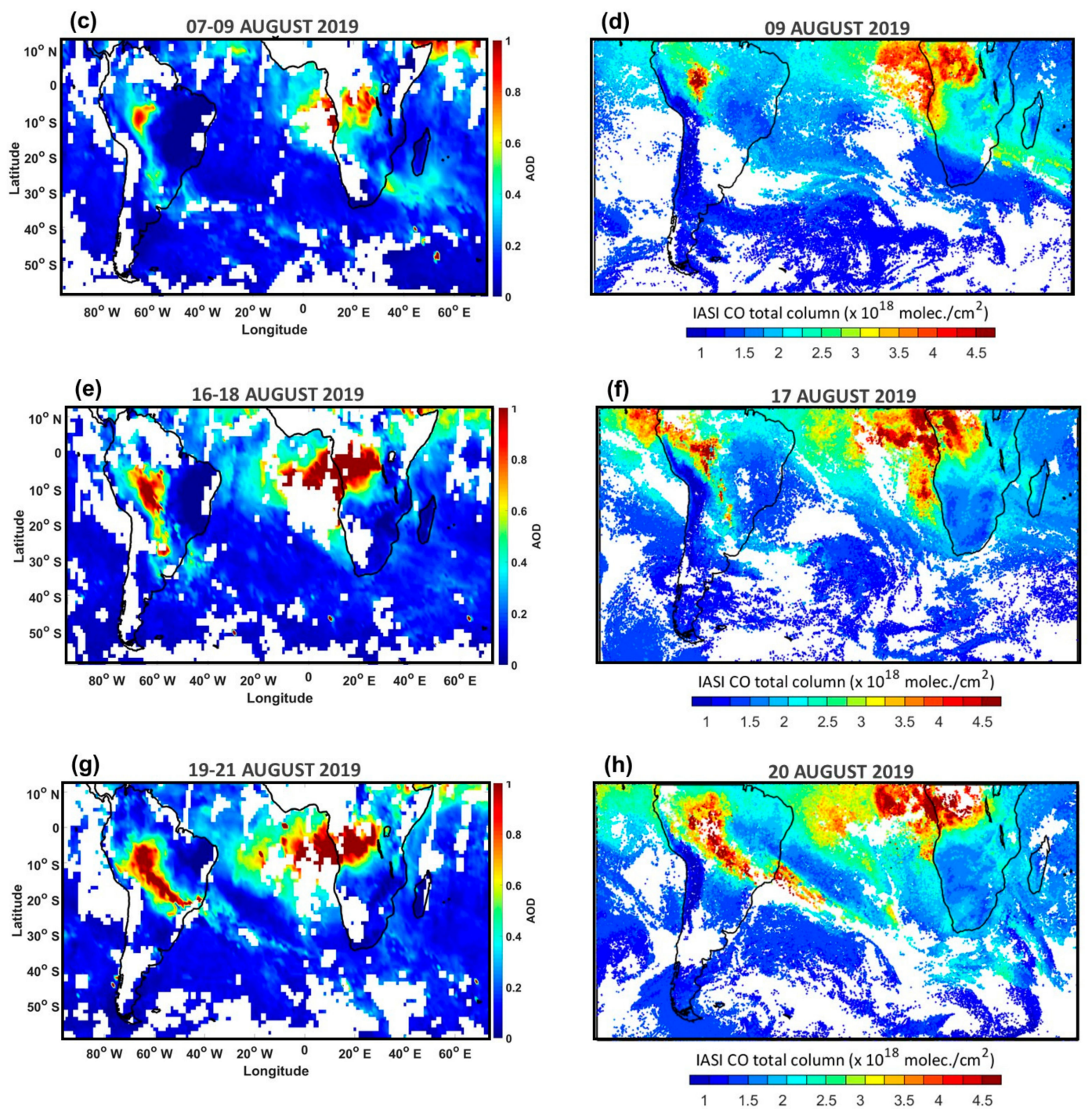

Figure 3. AOD at $550 \mathrm{~nm}$ (on left panels) and CO total columns (on right panels) from MODIS and IASI observations for the same selected dates (2, 9, 17 and 20 August 2019). MODIS AOD values are obtained by averaging observations from 3 consecutive days. 

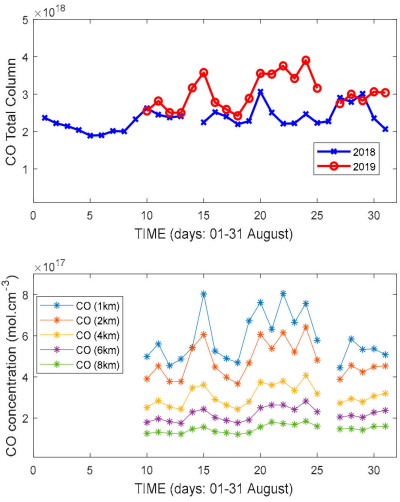

(a) Manicoré
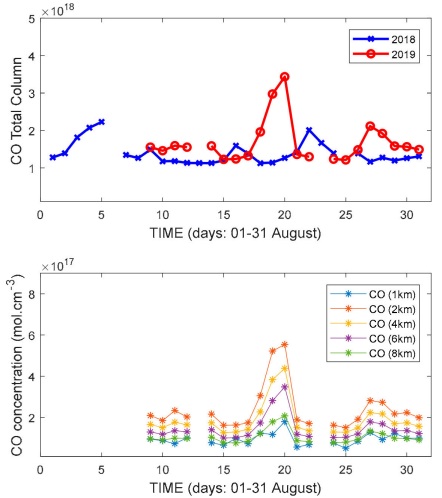

(b) São Paulo
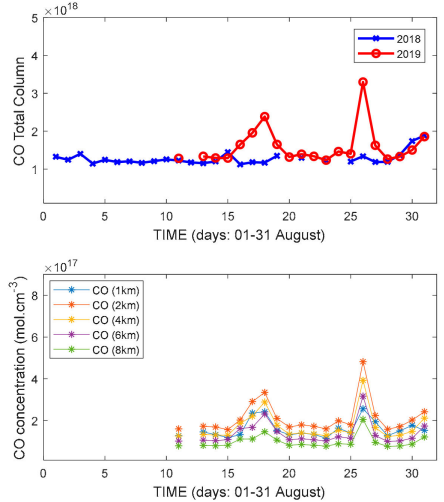

(c) Santa Maria

Figure 4. CO time evolution during August 2019, over (a) Manicoré (5.8 $\left.{ }^{\circ} \mathrm{S}, 61.3^{\circ} \mathrm{W}\right)$, (b) São Paulo $\left(23.5^{\circ} \mathrm{S}, 46.6^{\circ} \mathrm{W}\right)$ and $(\mathrm{c})$ Santa Maria $\left(29.4^{\circ} \mathrm{S}, 53.8^{\circ} \mathrm{W}\right)$ sites, as seen by IASI instrument. CO total columns are given in the upper panels, while CO concentrations at tropospheric heights $(1,2,4,6$ and $8 \mathrm{~km})$ are in the lower panels (according to the legend). For comparison, the August-2018 CO columns are superimposed in blue in the upper plots.

Besides satellite, ground based observations were used from a set of sun-photometers at the selected sites. Unfortunately, only the São Paulo and Santa Cruz sun-photometers were operating during the study period (August 2019). The AOD time-series obtained are depicted in Figure 5. The latter gives the temporal evolution of the daily AOD at São Paulo (Figure 5a) and Santa Cruz (Figure 5b) over an extended period from early August to mid-September. For comparison, AOD from MODIS experiment at the same wavelength $(550 \mathrm{~nm})$ and during the same period, together with monthly mean values (averaged over the three previous years, 2016-2018), are superimposed. For the São Paulo site there are two AOD significant peaks from sun-photometer records, one peak corresponding to the event of 18-19 August and the other one was around 27 August. However, only the August 18-19 event is visible on the MODIS AOD observations. This is in agreement with the events detected from CO-IASI values obtained over São Paulo (see Figure 4), which highlights the consistency between CO-IASI, AOD MODIS, and AOD-photometer datasets, at least for the detection of the August 18-19 event. It should be noted, however, that the daily AOD measured by MODIS appear to be lower than those obtained from ground-based observations by the sun-photometer. The obtained AOD distributions over São Paulo are in agreement with results reported by Bègue et al. [12]. In their study, Bègue et al. [12] found a mean bias error (MBE) between sun-photometer and MODIS observations of about 5.2\%. The AOD distribution at Santa Cruz (shown in Figure 5b) is higher than at São Paulo during August and September. The closer proximity of the Santa Cruz site (Bolivia) to the fire zone being a likely explanation. According to the Joint Research Centre (https://ec.europa.eu/jrc), Santa Cruz, the most populated city in Bolivia with nearly 2 million inhabitants, is the most affected by the Amazon fires in Bolivia. Figure 5b shows a high variability of AOD over Santa Cruz with many episodes between 10 and 25 August characterized by large increases (up to 2 times the background AOD values). Unlike São Paulo, the daily AOD values obtained by MODIS for Santa Cruz are often higher than those obtained by the sun-photometer during August. This irregularity is likely as a result of the high variability of AOD at the site during the study period, given its vicinity to the fire zone, and given the fact that the space resolution of MODIS (10 km-by-10 km grill) may not catch all the aerosol dynamics at small scales. Moreover, Figure 5a,b depicts the Angström exponent (AE) with green lines as derived from ground-based AOD at 440 and 675 nm wavelengths. For both sites (São Paulo and Santa Cruz), almost the same AE averaged values were observed ( 1.6). Taking into account air masses trajectories, these $\mathrm{AE}$ values suggest the presence of black carbon particles generated by BB activity. 


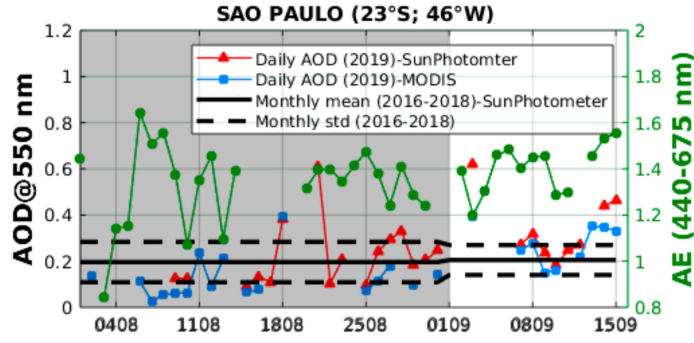

(a) Time (01 August - 15 September 2019)

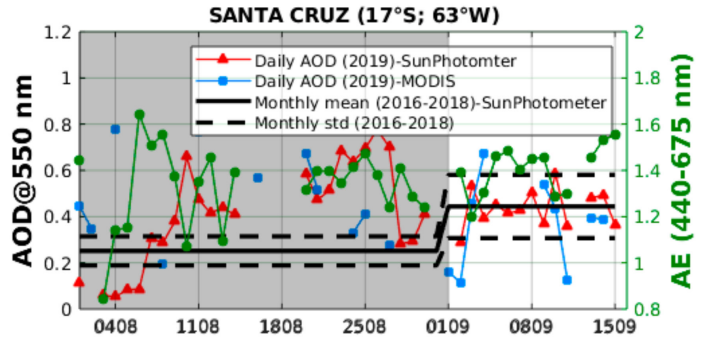

(b) Time (01 August - 15 September 2019)

Figure 5. Daily mean AOD values at $550 \mathrm{~nm}$ wavelength obtained by sun-photometer and MODIS at (a) São Paulo (Brazil) and (b) Santa Cruz (Bolivia). The study period is highlighted in grey. For comparison with the background situation, monthly mean sun-photometer over the 2016-2018 period are superimposed (continuous black lines) and framed with $\pm \sigma$ (see the legend). The green lines depict the Angström Exponent (given on the right vertical axe) for 440 and $675 \mathrm{~nm}$ wavelengths.

During the study period, the IPEN LiDAR at São Paulo operated for 21 days. However, for meteorological reasons, the LiDAR observations recorded on 18 August are isolated, with no measurements five days before and two days after. Figure 6 depicts LiDAR backscattered time-height cross-sections and the associated averaged range corrected signal (RCS) profiles at $532 \mathrm{~nm}$ wavelength obtained on 2nd and 18th August. The first case (2nd August) is used to show the situation without the influence of aerosols from fire plumes at the observation site. The RCS shown in Figure 6a,b was processed from 12:12 to 19:06 UTC (local time GMT-3). The aerosol boundary layer under $2000 \mathrm{~m}$ height is clearly observed, but with a low intensity, indicating a small number of aerosols. In addition to this, several low-level clouds (around $3 \mathrm{~km}$ height), mainly from 15:00 to 18:00 UTC, and some cirrus clouds between 10 and $11 \mathrm{~km}$ near 12:00 and 15:00 UTC. For the LiDAR measurements obtained on 18 August (Figure 6c,d), the RCS was processed over the whole period of observation, from 05:55 to 11:22 UTC. Some cloud structures in the 9-14 km layer of the upper troposphere may be associated with cirrus clouds. In fact, according to Landulfo et al. [40], the maximum cirrus cloud occurs in the 8-13 km altitude range during August over São Paulo. These authors used IPEN LiDAR backscatter profiles at $532 \mathrm{~nm}$ for the 2005-2008 period and showed that cirrus clouds build up during austral winter (June through September) over São Paulo. In the lower troposphere, an intense aerosol structure exceeding the boundary layer is clearly visible, getting stronger with time within the 1000-3000 m altitude range from 09 to 11 UTC (Figure $6 c, d$ ). This unusual type of aerosol layer could be associated with the long-range transport of fire aerosols, following the biomass burning episodes in the Amazon basin and the central part of Brazil. In fact, this was similar and in agreement with the AOD increases over São Paulo, observed by both the local sun-photometer and by MODIS space instrument (Figure 5a). It is also worth noting the consistency with the CO values obtained by IASI for São Paulo as illustrated on Figure $4 \mathrm{~b}$. All the observations utilized are consistent and indicate that São Paulo was under the influence of air masses loaded with aerosol particles and carbon monoxide, with a peak recorded on 18 August. 


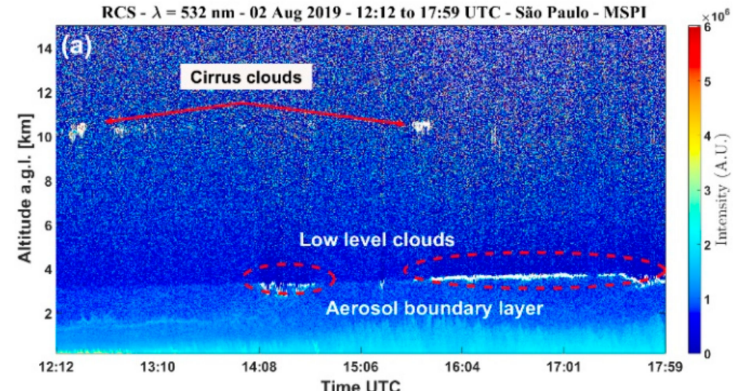

(a)

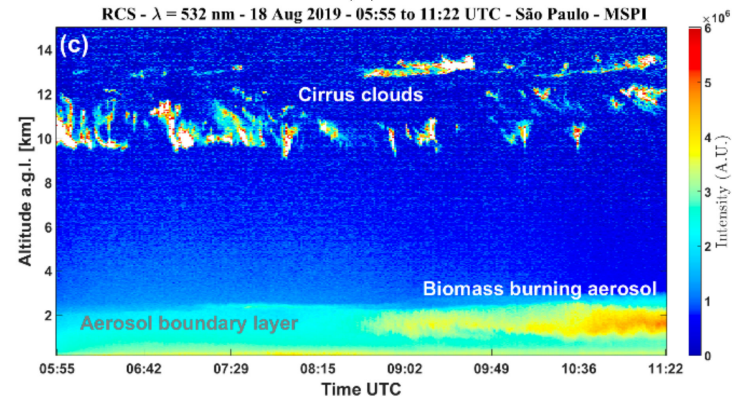

(c)

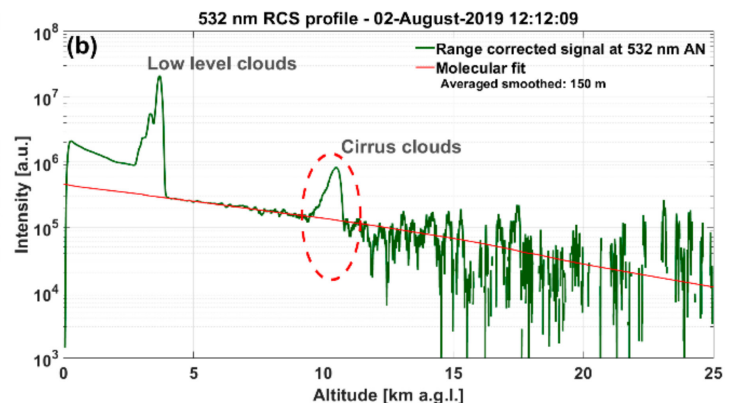

(b)

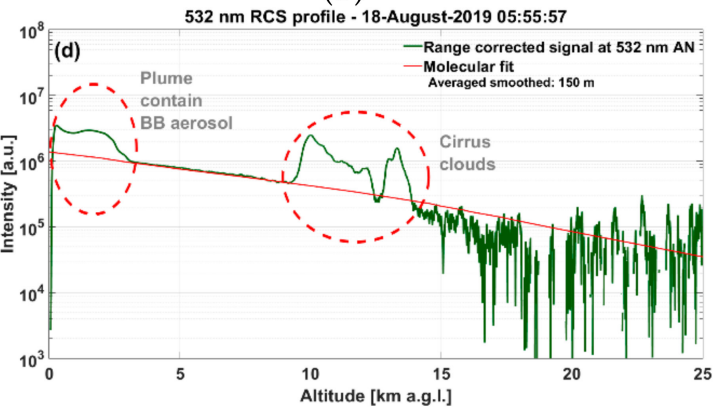

(d)

Figure 6. LiDAR corrected signal time-height cross-sections $(\mathbf{a}, \mathbf{c})$, and the associated averaged Range Corrected signal profiles (b,d) at $532 \mathrm{~nm}$ as recorded at São Paulo (Brazil) on 2nd and 18th August 2019, respectively. The red lines indicate the molecular contribution to the total backscattered signals.

\section{Transatlantic Transport}

In the previous section, the analysis of ground-based and satellite datasets highlighted an increase in $\mathrm{CO}$ and AOD loadings over Brazil, with an initial southward transport from fire zones nearby the equator. In effect, Figure $3 \mathrm{e}, \mathrm{f}$ indicates that $\mathrm{AOD}$ and $\mathrm{CO}$ values have increased, while showing a dispersion extending from the fire area to northern Argentina, at about $30^{\circ}$. It is clear from AOD and $\mathrm{CO}$ maps that this first phase was followed by a zonal eastward transport over the Atlantic Ocean. In a second stage, after 17 August, the trajectories of the Amazonian fire plumes tilted southeastward (Figure 3g,h). Subsequently reaching the Brazilian Eastern Atlantic coast, around August 18-19 and at about $20^{\circ} \mathrm{S}$ latitude, passing over São Paulo and Rio de Janeiro in the process, signifying the event that made a media buzz when it plunged the metropolis of São Paulo into darkness during daylight on August 19.

In this section, we investigate the transatlantic transport of the plume and its possible spread to Southern Africa and the southwestern Indian Ocean basin, based on CO and AOD distributions in addition to simulations by the FLEXPART model.

\subsection{Evidence from $\mathrm{CO}$ and Aerosol Distributions}

Figure 7 shows the daily variations of the total columns (upper plots) and concentrations in different atmospheric layers of daily CO values during August 2019, over Cape Point and Reunion sites. In general, both sites showed almost similar background CO levels as São Paulo and Santa Maria on the other side of the Atlantic Ocean. However, the CO column variations at Cape Point (at least between 10 and 27 August 2019), seem to be higher than those of August 2018, while the Reunion site did not show any significant variations on the recorded $\mathrm{CO}$ values. The authors assume that the circulation of the residual plume from Amazon fires did not affect Reunion during this time. In contrast, several CO peaks were detected for the Cape Point site, on the 14, 19, 22 and 25 August (see Figure 7a) respectively. The two events on 14 and 22 August will be analysed in the following section through FLEXPART model simulations. Moreover, considering the $\mathrm{CO}$ and AOD distribution maps in Figure 3, the first 
event can be associated to the ending of the first phase over Brazil, Paraguay, Argentina, and Uruguay, with an arrival of air-mass plumes on the Atlantic west coast around $30^{\circ}-33^{\circ} \mathrm{S}$ on the 8th August. Subsequently, an eastward zonal transport followed. Then, the second event of August 22nd can be associated with the major event of 18-19 August, which passed over São Paulo. This suggests that the transport of the plume took 3-4 days to cross the Atlantic and reach South Africa and the Indian Ocean.
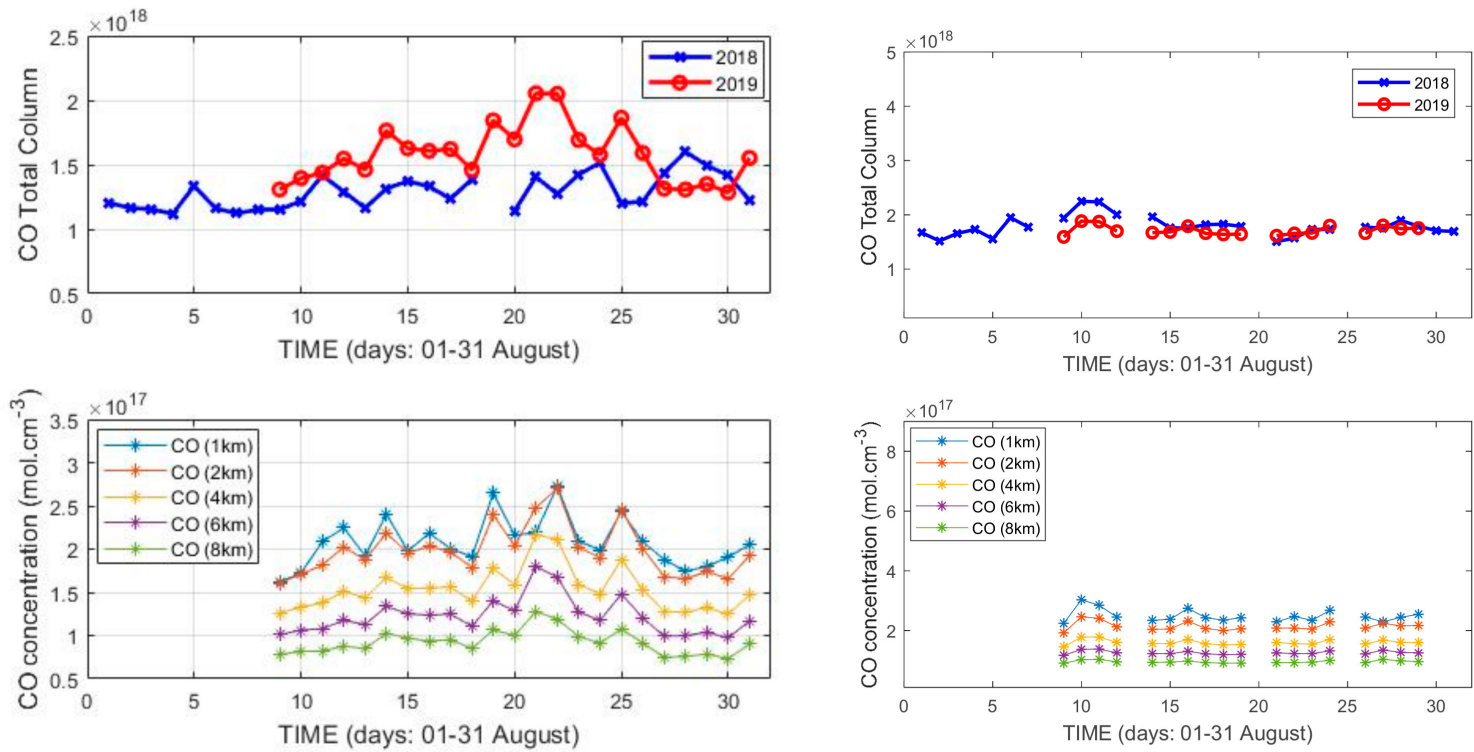

(a) Cape Point

(b) Reunion

Figure 7. Same as Figure 4, but for (a) Cape Point $\left(34.58^{\circ} \mathrm{S}, 18.83^{\circ} \mathrm{E}\right)$ and $(\mathbf{b})$ Reunion island $\left(21.18^{\circ} \mathrm{S}\right.$, $\left.55.88^{\circ} \mathrm{E}\right)$ sites.

CO from ground-based observations at Cape Point

Figure 8a shows the hourly time-evolution of CO mixing ratio recorded during August 2019 by the Picarro instrument at Cape Point. The local background CO during August 2019 was about 50-60 ppb. Using surface CO observations at CPT during the 1980-2016 period, Labuschagne et al. [33] reported that CO seasonal cycle at CPT shows a maximum in winter (70-80 ppb) and a minimum (40-50 ppb) in austral summer. Furthermore, Toihir et al. [41] used satellite observations and reported that the CO mixing ratio has been decreasing at Cape Point at the rate of 2.4\% over the 2005-2009 time-period. This was consistent with the observations of August 2019. Figure 8a showed that the background CO level was disturbed by some time-localized anomalies. The highest CO increase at Cape Point station was recorded on 14 August, with a very high CO mixing ratio, up to four times higher than the background value. It is noteworthy that the maximum CO mixing ratio from the 15-min values exceeded $400 \mathrm{ppb}$ on this day. One of the hypotheses to explain this large anomaly is the arrival of CO-rich air masses over Cape Point site. CO-IASI time-evolutions (Figure 7a) are consistent with this hypothesis and show an increase in $\mathrm{CO}$, especially in the $0-2 \mathrm{~km}$ altitude range. In conjunction, the map of CO-IASI total column of 14 August (Figure 8b) exhibits an increase in CO over the Cape Peninsula, seemingly in the pathway of the plume arriving from southern America across the Atlantic. 

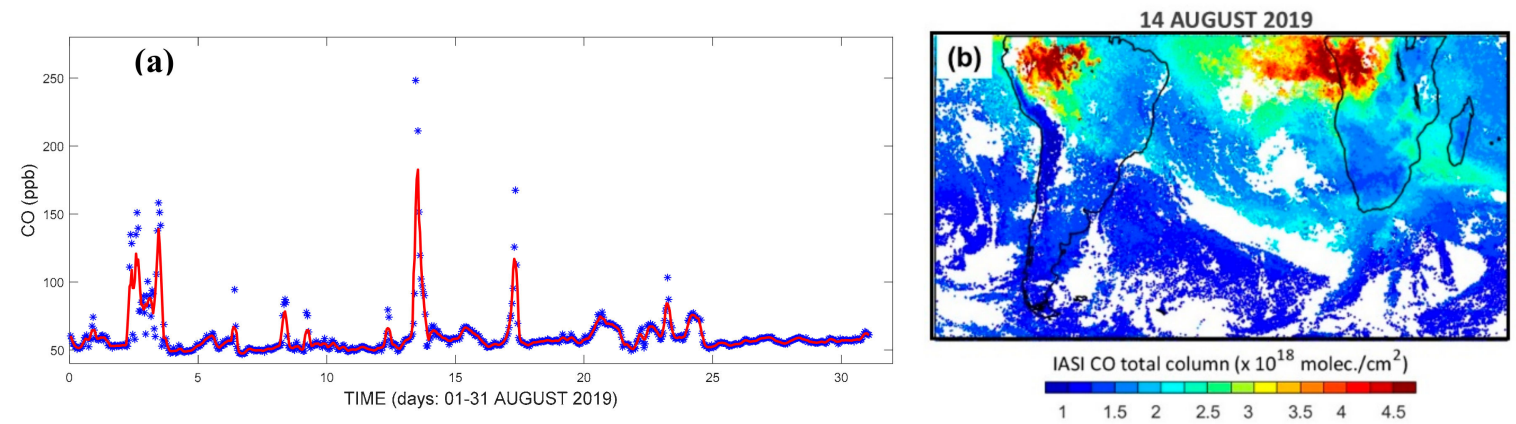

Figure 8. (a) Hourly CO values (blue stares symbols) recorded by the Picarro instrument at Cape Point GAW station during August 2019. The red curve represents a 5-h running average. (b) Map distribution of CO total columns from IASI observations on 14 August 2019.

\subsection{Transport and FLEXPART Simulations}

In this subsection, we investigate the transport events by using the FLEXPART model, specifically by analyzing the emission sensitivity (ES) parameter, which is the source-receptor relationship in FLEXPART simulations. Assuming that only transport occurs, the sensitivity of the measurement to a source region is proportional to the residence-time of the tracer particles. Thus, the ES in FLEXPART simulations relates to the residence-time of a particle in a grid cell. Therefore, high ES values indicate that the receptor was more sensitive to emissions from that region. The backward releases were initialized on 14 and 22 August from Cape Point location. For each event, backward dispersions in the form of ES of carbon monoxide are constructed for the 0-2, 2-4, and 4-6 km atmospheric layers. From the backward dispersion simulations for event-1 (Figure 9a-c (left)), a westerly trajectory is seen with stronger ES over the Amazon region in the lower two levels $(0-2 \mathrm{~km} /$ Figure $9 \mathrm{a}$ and 2-4 km/Figure 9b). In the upper level (4-6 km/Figure 9c), the ES over the Amazon is lower, with a trajectory passing over southern Brazil. As for event-2 (14-22 August 2019) (Figure 9e-f (right), a strong ES is seen over the southern parts of Brazil in the lower layer (0-2 km/Figure 9d). Furthermore, in the 4-6 km layer (Figure 9f), there is a strong ES towards the north of Cape Point, which presumably could be due the influence of African biomass burning.

Overall, FLEXPART simulations are in agreement with satellite and ground measurements observed over the study area and during the study period. They highlight and confirm a large-scale transport of air masses from the Amazon fire zone southwards over Brazil and neighbouring countries, subsequently associated with a zonal transatlantic transport, especially in the lower layers.

Several authors reported on large-scale transport across the Atlantic in the southern hemisphere at different atmospheric layers $[8,11,12,42,43]$. However, despite the seasonality of Amazon fires, none of these studies reported on such long-distance transport from the Amazon basin to Indian Ocean. In the present study, the large-scale transport is exacerbated by the increase in planetary Rossby wave activity during the study period. In fact, it is well known that planetary Rossby waves are mainly generated in the troposphere, that their activity increases during winter and they propagate vertically to the middle atmosphere with the westerly winds $[10,44]$. Moreover, Rossby wave propagation and breaking have been shown to play a critical role in transporting constituents out of the tropics into the extra-tropics, and vice versa [45-48]. Moreover, during the 2019 austral winter, the SH was under an increase in dynamic activity that led to a sudden stratospheric warming (SSW) event [49]. An SSW event is characterized by an increase in temperature and slowing of the mean zonal flow at the vicinity of the polar vortex, and it is preceded by the amplification of Rossby wave amplitudes in the winter hemisphere [45]. This suggests that, during the 2019 austral winter, the SH was subjected to an increase in Rossby wave activity that may have contributed to increasing the efficiency of large-scale transport of aerosol plumes generated by the Amazon fires during the study period. 


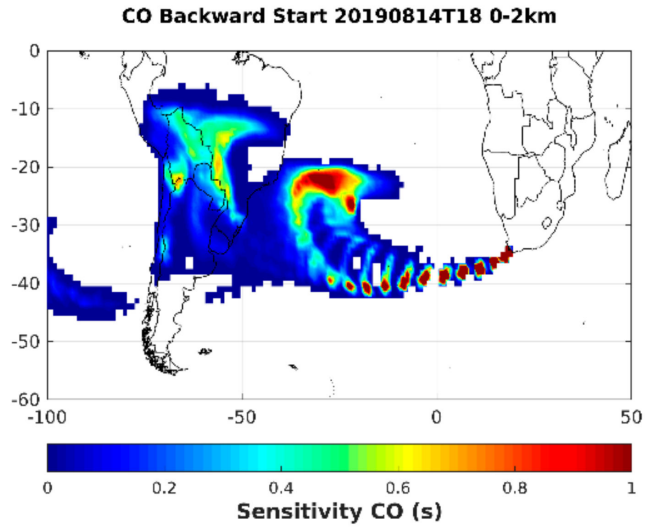

(a)

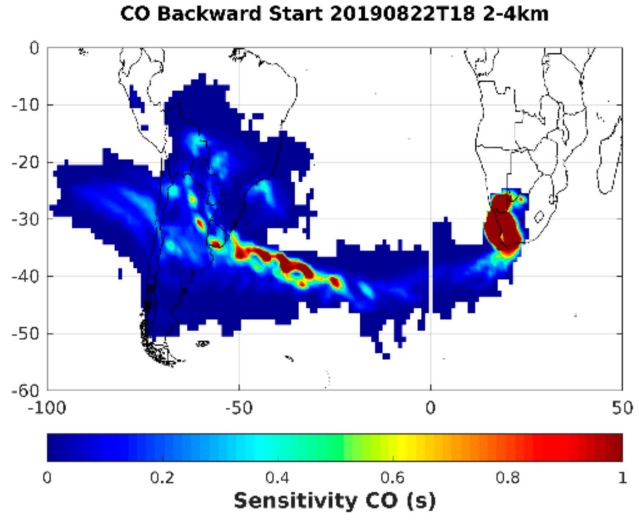

(c)

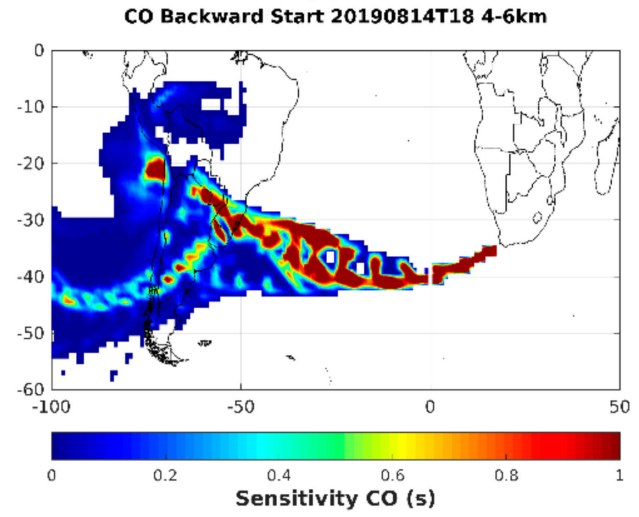

(e)

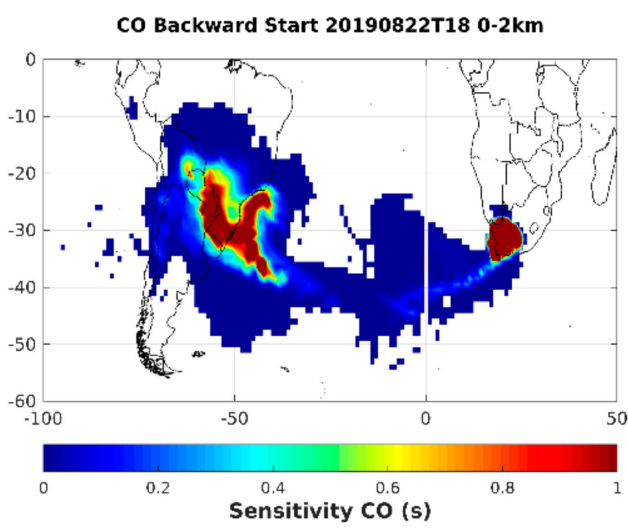

(b)

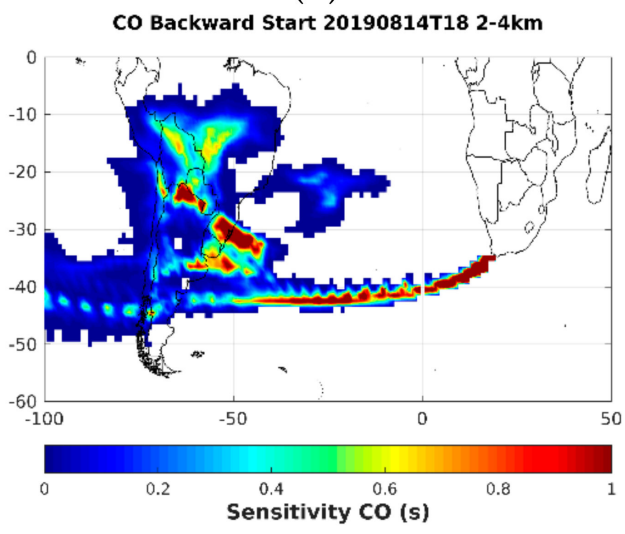

(d)

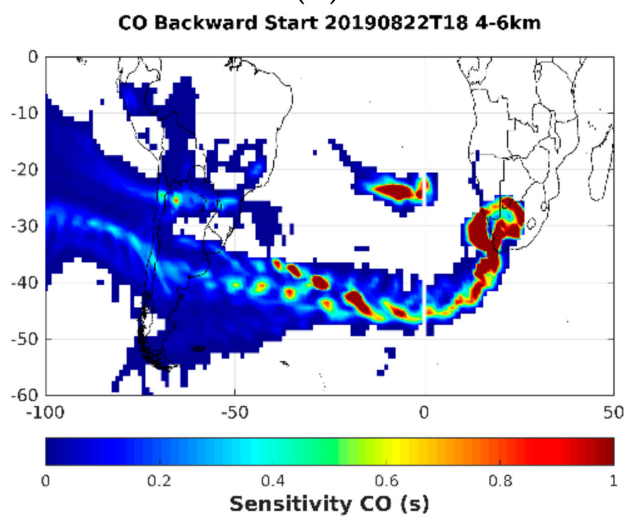

(f)

Figure 9. FLEXPART backward dispersion in terms of CO Emission Sensitivity for the two events. Simulations of event-1 (8 -14 August) are on the left panels, while simulations of event-2 (14-22 August) are on the right panels. Both simulations were made at consecutive atmospheric layers: $(\mathbf{a}, \mathbf{b})$ at $0-2 \mathrm{~km}$ (upper), (c,d) at 2-4 km (intermediate), (e,f) at 4-6 km (bottom).

\section{Conclusions}

In this paper, we used ground-based and satellite data to investigate long-range transport of plumes generated by Amazon fires during August 2019. AOD and CO distributions at different locations in the SH were used and supplemented by the FLEXPART model simulations. All ground and satellite observations showed increases in $\mathrm{CO}$ and AOD values and served to track air mass trajectories during the study period. Indeed, when analyzed in conjunction with the increase in fires activity 
(see Figure 2), it was observed that the transport of air masses from the source area took place in form of 2 successive events, which affected different locations in Southern America and in South Africa (see Figures 3 and 8). We identified two events: event-1 lasted from 7th to 14th August, and event-2 took place during the following week, from 14th to 22nd August. Event-1 spread initially southward from the source region in the Amazon basin along the Andes to about $30^{\circ} \mathrm{S}$ latitude, then followed by a zonal eastward transport across the Atlantic Ocean to reach Western Cape in South Africa and then into the Indian Ocean. For the second event, AOD and CO observations are consistent with each other and with simulations. They showed that the fire plumes moved by following a south-eastward direction, reaching the Brazilian Eastern Atlantic coast at about $20^{\circ} \mathrm{S}$ latitude and plunged São Paulo into darkness in daylight on August 19, before crossing the Atlantic Ocean to South Africa and the Indian Ocean. Generally, our datasets are consistent with each other and highlighted AOD and CO variations and transatlantic transport of fire plumes from the source regions in the Amazon basin. Moreover, we used the FLEXPART Lagrangian model to simulate the transport events. Overall, the obtained backward dispersion simulations are in good agreement with satellite and ground measurements observed over the study area and during the study period. They highlight and confirm a large-scale transport of air masses from the Amazon fire zone southwards over Brazil and neighbouring countries, subsequently associated with a zonal transatlantic transport, especially in the lower layers. It is recalled here that the $\mathrm{SH}$ was undergoing a stratospheric sudden warming event [49] resulting from an increase in Rossby wave activity, that may have contributed to the increased efficiency of large-scale transport of aerosol plumes generated by the Amazon fires during the study period. In the future, it is planned to perform a dynamic study of this large-scale transport case based on the use of appropriate numerical and modelling tools.

Author Contributions: Conceptualization, H.B.; methodology and software, H.B, N.B., D.J.d.P., L.S., F.J.d.S.L., J.-M.C., T.V., J.H.-L., and J.J.S.; validation and data curation, H.B., N.B., E.L., C.L., and C.C.; original draft preparation and writing, H.B.; review and editing, N.B., D.K.P., D.J.d.P., C.L., N.M., V.S., P.-F.C., and V.A.; project administration and funding acquisition, H.B. and D.K.P. All authors have read and agreed to the published version of the manuscript.

Funding: This research was funded jointly by the CNRS (Centre National de la Recherche Scientifique, France), CAPES (Coordenação de Aperfeiçoamento de Pessoal de Nível Superior, Brazil) and the NRF (National Research Foundation, South Africa) in the framework of the IRP ARSAIO, the COFECUB (project No Te 893/17) and the South Africa/France PROTEA Program (project No 42470VA). This work was supported by Universite de la Réunion through the OMNCG (Observatoire des Milieux Naturels et des Changements Globaux) federation of the OSU-Reunion (Observatoire des Sciences de l'Univers - La Reunion).

Acknowledgments: Authors acknowledge the French-Brazilian COFECUB programme, the French South-African PROTEA programme, the CNRS-NRF ARSAIO (Atmospheric Research in Southern Africa and Indian Ocean) International Research Programme for supporting research activities. Authors are thankful to the International Office (Direction des Relations Internationales) of Reunion University for travel supports and assistance with implementation of the agreements between the partners. IASI was developed and built under the responsibility of the "Centre National d'Etudes Spatiales" (CNES, France). It is flown on board the Metop satellites as part of the EUMETSAT Polar System. The authors thank the AERIS infrastructure (http://www.aeris-data.fr) for providing access to the IASI data, the National Aeronautical and Space Administration (NASA) for providing MODIS aerosol and fire products and the AERONET PIs (Brent Holben and Paulo Artaxo) and stations' staffs for establishing and maintaining the sun-photometers at Santa Cruz, Sao Paulo and Reunion (http://aeronet.gsfc.nasa.gov/).

Conflicts of Interest: The authors declare no conflict of interest.

\section{References}

1. Alves, N.D.O.; Vessoni, A.T.; Quinet, A.; Fortunato, R.S.; Kajitani, G.S.; Peixoto, M.S.; Hacon, S.D.S.; Artaxo, P.; Saldiva, P.; Menck, C.F.M.; et al. Biomass burning in the Amazon region causes DNA damage and cell death in human lung cells. Sci. Rep. 2017, 7, 1-13. [CrossRef]

2. Artaxo, P.; Martins, J.V.; Yamasoe, M.A.; Procópio, A.S.; Pauliquevis, T.M.; Andreae, M.O.; Guyon, P.; Gatti, L.V.; Leal, A.M.C. Physical and chemical properties of aerosols in the wet and dry seasons in Rondônia, Amazonia. J. Geophys. Res. Space Phys. 2002, 107, LBA 49-1. [CrossRef] 
3. Crutzen, P.J.; Carmichael, G.R. Modeling the Influence of Fires on Atmospheric Chemistry, in Fire in the Environment: The Ecological, Atmospheric, and Climatic Importance of Vegetation Fires; John Wiley: New York, NY, USA, 1993; pp. 89-106.

4. Thompson, A.M.; Balashov, N.V.; Witte, J.C.; Coetzee, J.G.R.; Thouret, V.; Posny, F. Tropospheric ozone increases over the southern Africa region: Bellwether for rapid growth in Southern Hemisphere pollution? Atmos. Chem. Phys. Discuss. 2014, 14, 9855-9869. [CrossRef]

5. Bertschi, I.T.; Jaffe, D.A.; Jaegle, L.; Price, H.; Dennison, J.B. PHOBEA/ITCT 2002 airborne observations of transpacific transport of ozone, $\mathrm{CO}$, volatile organic compounds, and aerosols to the northeast Pacific: Impacts of Asian anthropogenic and Siberian boreal fire emissions. J. Geophys. Res. Space Phys. 2004, 109. [CrossRef]

6. Clain, G.; Baray, J.L.; Delmas, R.; Diab, R.; Leclair de Bellevue, J.; Keckhut, P.; Posny, F.; Metzger, J.M.; Cammas, J.P. Tropospheric ozone climatology at two Southern Hemisphere tropical/subtropical sites, (Reunion Island and Irene, South Africa) from ozonesondes, LIDAR, and in situ aircraft measurements. Atmos. Chem. Phys. 2009, 9, 1723-1734. [CrossRef]

7. Anderson, D.C.; Nicely, J.M.; Salawitch, R.J.; Canty, T.P.; Dickerson, R.R.; Hanisco, T.F.; Wolfe, G.M.; Apel, E.C.; Atlas, E.; Bannan, T.; et al. A pervasive role for biomass burning in tropical high ozone/low water structures. Nat. Commun. 2016, 7, 10267. [CrossRef]

8. Duflot, V.; Dils, B.; Baray, J.-L.; De Mazière, M.; Attié, J.L.; Vanhaelewyn, G.; Senten, C.; Vigouroux, C.; Clain, G.; Delmas, R. Analysis of the origin of the distribution of CO in the subtropical southern Indian Ocean in 2007. J. Geophys. Res. Space Phys. 2010, 115. [CrossRef]

9. Torres, O.; Tanskanen, A.; Veihelmann, B.; Ahn, C.; Braak, R.; Bhartia, P.K.; Veefkind, P.; Levelt, P.P. Aerosols and surface UV products from Ozone Monitoring Instrument observations: An overview. J. Geophys. Res. Space Phys. 2007, 112. [CrossRef]

10. Bencherif, H.; Portafaix, T.; Baray, J.-L.; Morel, B.; Baldy, S.; Leveau, J.; Hauchecorne, A.; Keckhut, P.; Moorgawa, A.; Michaelis, M.; et al. LIDAR observations of lower stratospheric aerosols over South Africa linked to large scale transport across the southern subtropical barrier. J. Atmos. Sol. Terr. Phys. 2003, 65, 707-715. [CrossRef]

11. Anonymous Review of "Long-range isentropic transport of stratospheric aerosols over Southern Hemisphere following the Calbuco eruption in April 2015". Atmos. Chem. Phys. 2017, 17, 15019-15036. [CrossRef]

12. Bègue, N.; Shikwambana, L.; Bencherif, H.; Pallotta, J.; Sivakumar, V.; Wolfram, E.; Mbatha, N.; Orte, F.; Du Preez, D.J.; Ranaivombola, M.; et al. Statistical analysis of the long-range transport of the 2015 Calbuco volcanic plume from ground-based and space-borne observations. Ann. Geophys. 2020, 38, 395-420. [CrossRef]

13. Duflot, V.; Royer, P.; Chazette, P.; Baray, J.-L.; Courcoux, Y.; Delmas, R. Marine and biomass burning aerosols in the southern Indian Ocean: Retrieval of aerosol optical properties from shipborne lidar and Sun photometer measurements. J. Geophys. Res. Space Phys. 2011, 116. [CrossRef]

14. Pelletier, C. Méthodologie de détection des feux de forêt à partir d'images satellitaires NOAA. Master's Thesis, Université du Québec à Chicoutimi, Chicoutimi, QC, Canada, 2001.

15. Kaufman, Y.J.; Justice, C.O.; Flynn, L.P.; Jendall, J.D.; Prins, E.M.; Giglio, L.; Ward, D.E.; Menzel, W.P.; Setzer, A.W. Monitoring global fire monitoring from EOS-MODIS. J. Geophys. Res. 1998, 103, 315-338. [CrossRef]

16. Giglio, L.; Schroeder, W.; Justice, C.O. The collection 6 MODIS active fire detection algorithm and fire products. Remote. Sens. Environ. 2016, 178, 31-41. [CrossRef] [PubMed]

17. Clerbaux, C.; Boynard, A.; Clarisse, L.; George, M.; Hadji-Lazaro, J.; Herbin, H.; Hurtmans, D.; Pommier, M.; Razavi, A.; Turquety, S.; et al. Monitoring of atmospheric composition using the thermal infrared IASI/MetOp sounder. Atmos. Chem. Phys. 2009, 9, 6041-6054. [CrossRef]

18. George, M.; Clerbaux, C.; Hurtmans, D.; Turquety, S.; Coheur, P.-F.; Pommier, M.; Hadji-Lazaro, J.; Edwards, D.P.; Worden, H.; Luo, M.; et al. Carbon monoxide distributions from the IASI/METOP mission: Evaluation with other space-borne remote sensors. Atmos. Chem. Phys. 2009, 9, 8317-8330. [CrossRef]

19. Turquety, S.; Hurtmans, J.D.; Hadji-Lazaro, P.-F.; Coheur, C.; Clerbaux, D.; Josset, C.T. Tracking the emission and transport of pollution from wildfires using the IASI CO retrievals: Analysis of the summer 2007 Greek fires. Atmos. Chem. Phys. 2009, 9, 4897-4913. [CrossRef] 
20. Nechita-Banda, N.; Krol, M.; Van Der Werf, G.R.; Kaiser, J.W.; Pandey, S.; Huijnen, V.; Clerbaux, C.; Coheur, P.; Deeter, M.N.; Röckmann, T. Monitoring emissions from the 2015 Indonesian fires using CO satellite data. Philos. Trans. R. Soc. B Biol. Sci. 2018, 373, 20170307. [CrossRef]

21. Turquety, S.; Menut, L.; Siour, G.; Mailler, S.; Hadji-Lazaro, J.; George, M.; Clerbaux, C.; Hurtmans, D.; Coheur, P.-F. APIFLAME v2.0 biomass burning emissions model: Impact of refined input parameters on atmospheric concentration in Portugal in summer 2016. Geosci. Model Dev. 2020, 13, 2981-3009. [CrossRef]

22. Holben, B.; Eck, T.; Slutsker, I.; Tanré, D.; Buis, J.; Setzer, A.; Vermote, E.; Reagan, J.; Kaufman, Y.; Nakajima, T.; et al. AERONET-A Federated Instrument Network and Data Archive for Aerosol Characterization. Remote. Sens. Environ. 1998, 66, 1-16. [CrossRef]

23. Dubovik, O.; King, M.D. A flexible inversion algorithm for retrieval of aerosol optical properties from Sun and sky radiance measurements. J. Geophys. Res. 2000, 105, 20673-20696. [CrossRef]

24. Dubovik, O.; Smirnov, A.; Holben, B.N.; King, M.D.; Kaufman, Y.J.; Eck, T.F.; Slutsker, Y. Accuracy assessment of aerosol optical properties retrieval from AERONET sun and sky radiance measurements. J. Geophys. Res. 2000, 105, 9791-9806. [CrossRef]

25. Eck, T.F.; Holben, B.N.; Reid, J.S.; Dubovik, O.; Smirnov, A.; O’Neill, I.; Slutsker, N.T.; Kinne, S. Wavelength dependence of the optical depth of biomass burning, urban, and desert dust aerosols. J. Geophys. Res. 1999, 104, 31333-31349. [CrossRef]

26. Eck, T.F.; Holben, B.N.; Reid, J.S.; O’Neill, N.T.; Schafer, J.S.; Dubovik, O.; Smirnov, A.; Yamasoe, M.A.; Artaxo, P. High aerosol optical depth biomass burning events: A comparison of optical properties for different source regions. Geophys. Res. Lett. 2003, 30. [CrossRef]

27. Giles, D.M.; Sinyuk, A.; Sorokin, M.G.; Schafer, J.S.; Smirnov, A.; Slutsker, I.; Eck, T.F.; Holben, B.; Lewis, J.R.; Campbell, J.R.; et al. Advancements in the Aerosol Robotic Network (AERONET) Version 3 database-Automated near-real-time quality control algorithm with improved cloud screening for Sun photometer aerosol optical depth (AOD) measurements. Atmos. Meas. Tech. 2019, 12, 169-209. [CrossRef]

28. Hauchecorne, A.; Chanin, M.L. Density and temperature profiles obtained by lidar between $35 \mathrm{and} 70 \mathrm{~km}$. Geophys. Res. Lett. 1980, 7, 565-568. [CrossRef]

29. Lopes, F.; Silva, J.J.; Marrero, J.C.A.; Taha, G.; Landulfo, E. Synergetic Aerosol Layer Observation After the 2015 Calbuco Volcanic Eruption Event. Remote. Sens. 2019, 11, 195. [CrossRef]

30. Guerrero-Rascado, J.L.; Landulfo, E.; Antuña, J.C.; Barbosa, H.D.M.J.; Barja, B.; Bastidas, Á.E.; Bedoya, A.E.; Da Costa, R.F.; Estevan, R.; Forno, R.; et al. Latin American Lidar Network (LALINET) for aerosol research: Diagnosis on network instrumentation. J. Atmos. Sol. Terr. Phys. 2016, 138, 112-120. [CrossRef]

31. Labuschagne, C.; Kuyper, B.; Brunke, E.-G.; Mokolo, T.; van der Spuy, D.; Martin, L.; Parker, B.; Khan, M.A.H.; Joubert, W.; Coleman, M.T.D.; et al. A review of four decades of atmospheric trace gas measurements at Cape Point, South Africa. Transact. R. Soc. S. Afr. 2018. [CrossRef]

32. Brunke, E.-G.; Labuschagne, C.; Parker, B.; Scheel, H.; Whittlestone, S. Baseline air mass selection at Cape Point, South Africa: Application of 222Rn and other filter criteria to CO2. Atmos. Environ. 2004, 38, 5693-5702. [CrossRef]

33. Whittlestone, S.; Kowalczyk, E.; Brunke, E.G.; Labuschagne, C. Source regions for CO2 at Cape Point assessed by modelling, 222Rn and meteorological data; South African Weather Service: Pretoria, South Africa, 2009; ISBN 978-0-9584463-9-6.

34. Chen, H.; Karion, A.; Rella, C.W.; Winderlich, J.; Gerbig, C.; Filges, A.; Newberger, T.; Sweeney, C.; Tans, P.P. Accurate measurements of carbon monoxide in humid air using the cavity ring-down spectroscopy (CRDS) technique. Atmos. Meas. Tech. 2013, 6, 1031-1040. [CrossRef]

35. Pisso, I.; Sollum, E.; Grythe, H.; Kristiansen, N.I.; Cassiani, M.; Eckhardt, S.; Arnold, D.; Morton, D.; Thompson, R.L.; Zwaaftink, C.D.G.; et al. The Lagrangian particle dispersion model FLEXPART version 10.4. Geosci. Model Dev. 2019, 12, 4955-4997. [CrossRef]

36. Thakur, J.; Thever, P.; Gharai, B.; Sai, M.S.; Pamaraju, V. Enhancement of carbon monoxide concentration in atmosphere due to large scale forest fire of Uttarakhand. Peer] 2019, 7, e6507. [CrossRef] [PubMed]

37. Lutsch, E.; Dammers, E.; Conway, S.; Strong, K. Long-range transport of NH3, CO, HCN, and C2H6 from the 2014 Canadian Wildfires. Geophys. Res. Lett. 2016, 43, 8286-8297. [CrossRef]

38. Paris, J.-D.; Stohl, A.; Nédélec, P.; Arshinov, M.Y.; Panchenko, M.V.; Shmargunov, V.P.; Law, K.S.; Belan, B.D.; Ciais, P. Wildfire smoke in the Siberian Arctic in summer: Source characterization and plume evolution from airborne measurements. Atmos. Chem. Phys. 2009, 9, 9315-9327. [CrossRef] 
39. Damoah, R.; Spichtinger, N.; Forster, C.; James, P.; Mattis, I.; Wandinger, U.; Beirle, S.; Wagner, T.; Stohl, A. Around the world in 17 days-Hemispheric-scale transport of forest fire smoke from Russia in May 2003. Atmos. Chem. Phys. 2004, 4, 1311-1321. [CrossRef]

40. Landulfo, E.; Larroza, E.G.; Lopes, F.; Hoareau, C. A preliminary classification of cirrus clouds over Sao Paulo city by systematic lidar observations and comparison with CALIPSO and AERONET data. SPIE Eur. Remote Sens. 2009, 7475, 747506. [CrossRef]

41. Toihir, A.; Venkataraman, S.; Mbatha, N.; Sangeetha, S.; Bencherif, H.; Brunke, E.-G.; Labuschagne, C.; Sivakumar, V. Studies on CO variation and trends over South Africa and the Indian Ocean using TES satellite data. South Afr. J. Sci. 2015, 111. [CrossRef]

42. Du Preez, D.J.; Bencherif, H.; Bègue, N.; Clarisse, L.; Hoffman, R.F.; Wright, C.Y. Investigating the Large-Scale Transport of a Volcanic Plume and the Impact on a Secondary Site. Atmosphere 2020, 11, 548. [CrossRef]

43. Edwards, D.P.; Pétron, G.; Novelli, P.C.; Emmons, L.K.; Gille, J.C.; Drummond, J.R. Southern Hemisphere carbon monoxide interannual variability observed by Terra/(MOPITT). J. Geophys. Res. 2006, 111, D16303. [CrossRef]

44. Leovy, C.; Sun, C.-R.; Hitchman, M.; Remsberg, E.E.; Russell, J.; Gordley, L.; Gille, J.; Lyjak, L. Transport of Ozone in the Middle Stratosphere: Evidence for Planetary Wave Breaking. J. Atmos. Sci. 1985, 42, 230-244. [CrossRef]

45. Homeyer, C.R.; Bowman, K.P. Rossby Wave Breaking and Transport between the Tropics and Extratropics above the Subtropical Jet. J. Atmos. Sci. 2013, 70, 607-626. [CrossRef]

46. Bencherif, H.; El Amraoui, L.; Semane, N.; Massart, S.; Charyulu, D.V.; Hauchecorne, A.; Peuch, V.-H. Examination of the 2002 major warming in the southern hemisphere using ground-based and Odin/SMR assimilated data: Stratospheric ozone distributions and tropic/mid-latitude exchange. Can. J. Phys. 2007, 85, 1287-1300. [CrossRef]

47. Semane, N.; Bencherif, H.; Morel, B.; Hauchecorne, A.; Diab, R.D. An unusual stratospheric ozone decrease in the Southern Hemisphere subtropics linked to isentropic air-mass transport as observed over Irene $\left(25.5^{\circ} \mathrm{S}\right.$, 28.1 ${ }^{\circ}$ E) in mid-May 2002. Atmos. Chem. Phys. 2006, 6, 1927-1936. [CrossRef]

48. Sivakumar, V.; Morel, B.; Bencherif, H.; Baray, J.L.; Baldy, S.; Hauchecorne, A.; Rao, P.B. Rayleigh lidar observation of a warm stratopause over a tropical site, Gadanki $\left(13.5^{\circ} \mathrm{N} ; 79.2^{\circ} \mathrm{E}\right)$. Atmos. Chem. Phys. 2004, 4 , 1989-1996. [CrossRef]

49. Yamazaki, Y.; Matthias, V.; Miyoshi, Y.; Stolle, C.; Siddiqui, T.; Kervalishvili, G.; Laštovička, J.; Kozubek, M.; Ward, W.; Themens, D.R.; et al. September 2019 Antarctic Sudden Stratospheric Warming: Quasi-6-Day Wave Burst and Ionospheric Effects. Geophys. Res. Lett. 2020, 47. [CrossRef]

Publisher's Note: MDPI stays neutral with regard to jurisdictional claims in published maps and institutional affiliations.

(C) 2020 by the authors. Licensee MDPI, Basel, Switzerland. This article is an open access article distributed under the terms and conditions of the Creative Commons Attribution (CC BY) license (http://creativecommons.org/licenses/by/4.0/). 